Взаємодія органів публічної влади та молодіжних громадських об'єднань щодо підготовки стратегічних документів у сфері молодіжної політики в країнах ЄС

\author{
Тетяна Несват, Дніпропетровський регіональний інститут державного управління \\ Національної академії державного управління при Президентові України
}

Молодіжна політика $Є \mathrm{C}$ дуже динамічна проте з різним темпом розвитку у кожній країні. Основною функцією молодіжної політики в СС є мотивація та надання підтримки в прийнятті обгрунтованих життєвих рішень, що сприяють особистому та соціальному розвитку молоді і розвитку суспільства в цілому. Досягнення цієї мети можливо лише при розширенні можливостей молодих громадян $\mathrm{i}$ ïx активного залучення в підготовку, реалізацію та оцінку ефективності ініціатив і заходів, що відображають потреби, інтереси, ідеї і досвід молоді.

Проте для побудови єдиного європейського громадянського простору необхідно враховувати національні особливості кожної країни ЄС та реалізацію державної молодіжної політики кожної держави окремо.

Оскільки питання взаємозв'язку між органами публічної влади з різними суб'єктами молодіжної політики у країнах Європейського Союзу досі залишається мало вивченим, а комплексний підхід до вивчення європейської молодіжної політики відсутній, нами було проаналізовано стан взаємодії органів публічної влади та представників молодіжних об'єднань ЄС щодо підготовки національних стратегій розвитку молодіжної політики, таких країн як Франція, Німеччина, Польща, Угорщина, Чехія.

Метою статті є дослідження проблеми взаємодії органів влади та молодіжних об'єднань на прикладі залучення молодих громадян до розробки та впровадження нормативно-правових актів в деяких країнах $\mathrm{CC}$ та обгрунтувати пропозиції щодо реалізації Стратегії розвитку державної молодіжної політики України 2030 року.

У статті зауважується про недосконалість комплексного підходу у реалізації молодіжної роботи в євроспільноті. Запропоновано використати кращі результати співпраці влади і молоді Свропи у впроваджені дорожньої карти молодіжної роботи в Україні та використання інструменту - Індекс благополуччя молоді для моніторингу молодіжної політики та виконання стратегії. Звертається увага на доцільність використання двокомпонентного підходу у реалізації державної молодіжної політики, зокрема у досягненні мети стратегії, а саме досягнення цілей сталого розвитку через реалізацію молодіжної політики та реалізація державної молодіжної політики через цілі сталого розвитку.

Ключові слова: державна молодіжна політика, європейський громадянський простір, індекс благополуччя молоді, молодь, молодіжні об'єднання, стратегія

\title{
Cooperation between public authorities and non-governmental youth associations in preparing the strategic documents in the field of youth policy in EU countries
}

\section{Tetiana Nesvat, Dnipropetrovsk Regional Institute of Public Administration National Academy of Public Administration under the President of Ukraine}

EU youth policy is very dynamic, but with different rates of development in each EU country. The main purpose of youth policy in the EU is to motivate and support making informed life decisions that contribute to the personal and social development of young people and the development of society as a whole. Accomplishing this goal is possible only by empowering the young citizens and their active involvement in the preparation, implementation and evaluation of the initiatives and activities efficiency that reflect the needs, interests, ideas and experiences of young people. 
However, in order to establish a common European civic space, it is necessary to consider the national circumstances of each EU country and the implementation of the state youth policy of each state separately.

As the issue of the relationship between public authorities with various youth policy actors in the European Union remains under-explored, and a comprehensive approach to the study of European youth policy is missing, we analyzed the state of interaction between public authorities and EU youth associations on preparing the national development strategies for youth policy, such as France, Germany, Poland, Hungary, the Czech Republic.

The aim of the article is to study the problem of interaction between government agencies and youth associations on the example of attracting young citizens in the development and implementation of regulations in some EU countries and to justify proposals for implementing the Strategy for State Youth Policy of Ukraine 2030.

The article clarifies the imperfection of a comprehensive approach to the implementation of youth work in the European community. It is proposed to use the best results of cooperation between the authorities and the youth of Europe in the implementation of the guidelines for youth work in Ukraine and the use of the tool - Youth Welfare Index for monitoring the youth policy and strategy implementation. Attention is paid to the feasibility of using a two-component approach in the implementation of state youth policy, in particular in achieving the strategy, namely achieving sustainable development goals through the implementation of youth policy and the implementation of state youth policy through sustainable development goals.

Keywords: youth policy, strategy, European civic space, youth welfare index, youth associations

\section{Взаимодействиеоргановпубличной власти имолодежныхобщественных объединений по подготовке стратегических документов в сфере молодежной политики в странах ЕС}

\section{Татьяна Несват, Днепропетровский региональный институт государственного управления Национальной академии государственного управления при Президенте Украины}

Молодежная политика ЕС очень динамичная, но с разным темпом развития в каждом государстве. Основной функцией молодежной политики в ЕС является мотивация и оказание поддержки в принятии обоснованных жизненных решений, способствующих личному и социальному развитию молодежи и развитию общества в целом. Достижение этих целей возможно лишь при расширении возможностей молодых граждан и их активного вовлечения в подготовку, реализацию и оценку эффективности инициатив и мероприятий, отражающих потребности, интересы, идеи и опыт молодежи.

Для построения единого европейского гражданского пространства необходимо учитывать национальные особенности каждого государства-члена ЕС и реализацию государственной молодежной политики каждой страны в отдельности.

Вопрос взаимосвязи между органами публичной власти с различными субъектами молодежной политики в странах Европейского Союза до сих пор остается мало изученным, а комплексный подход к изучению европейской молодежной политики отсутствует, нами было проанализировано состояние взаимодействия органов публичной власти и представителей молодежных объединений ЕС по подготовке национальных стратегий развития молодежной политики, таких стран как Франция, Германия, Польша, Венгрия, Чехия.

Целью статьи является исследование проблемы взаимодействия органов власти и молодежных объединений на примере привлечения молодых граждан к разработке и внедрению нормативно-правовых актов в некоторых странах ЕС и обоснование предложения по реализации Стратегии развития государственной молодежной политики Украины 2030 года.

В статье отмечается несовершенство комплексного подхода в реализации молодежной работы в евросообществе. Предложено использовать лучшие результаты сотрудничества власти и молодежи Европы во внедрении дорожной карты молодежной работы в Украине и использование инструмента Индекс благополучия молодежи для мониторинга молодежной политики и выполнения стратегии. Обращается внимание на целесообразность использования двухкомпонентного подхода в реализации 
государственной молодежной политики, в частности в достижении цели стратегии, а именно достижение целей устойчивого развития через реализацию молодежной политики и реализация государственной молодежной политики через цели устойчивого развития.

Ключевые слова: молодежная политика, стратегия, европейское гражданское пространство, индекс благополучия молодежи, молодежные объединения.

$\mathrm{H}$ е дивлячись на всі виклики, які постали перед $Є С$ в останній час, європейська спільнота продовжує створювати єдиний політичний, соціально-економічний майданчик, який об’єднує всі європейські цінності та створює єдиний європейський громадянський простір. Особлива роль у формуванні європейського громадянського простору відведена молоді.

Розвиток молоді у європейському громадянському просторі відбувається у 4 векторах - політичний, економічний, соціальний, культурний. Результат у цих напрямах цілком залежить від соціалізації молодих громадян $\mathrm{CC}$, яка відбувається у начальних закладах, молодіжних центрах, громадських об’єднаннях та молодіжних крилах політичних партій.

Основною функцією молодіжної політики в $€ \mathrm{C} є$ мотивація та надання підтримки в прийнятті обгрунтованих життєвих рішень, що сприяють особистому та соціальному розвитку молоді і розвитку суспільства в цілому. Досягнення цієї мети можливо лише при розширенні можливостей молодих громадян і їх активного залучення в підготовку, реалізацію та оцінку ефективності ініціатив і заходів, що відображають потреби, інтереси, ідеї і досвід молоді (Молодежная работа, 2017).

Вивченням та аналізом стану розвитку молодіжної політики в Свропі протягом багатьох років займаються вітчизняні та закордонні вчені, такі як: С. Грачов, М. Обіход, В. Смирнов, Р. Сторожук, Г. Вільямсон (H. Williamson), К. Гомолка (К. Gomółka), Дж. О’Донован (J. O’Donovan), Н. Падісон (N. Padison) та ін. Проте питання взаємозв'язку органів публічної влади з різними суб'єктами молодіжної політики у країнах
ЄC досі залишається мало вивченим, що актуалізує науковий інтерес до цього питання.

У дослідженнях підкреслюється, що основною метою молодіжної політики в сучасній Європі є створення можливостей для розвитку молоді та формування ресурсної бази для використання цих можливостей. Крім того, ціллю виступає й інтеграція молодих громадян у суспільство та розкриття їх можливостей (Баронина, \& Зуляр, 2019). Проте для побудови єдиного європейського громадянського простору необхідно враховувати національні особливості кожної країни СС та реалізацію державної молодіжної політики кожної держави окремо.

В останній час молодь в Європі сприймається не тільки як ресурс майбутнього розвитку суспільства, а і як особлива соціальна група, яка вже може внести істотний внесок у соціальні перетворення $\mathrm{CC}$, який цілком залежить від соціальної активності молоді. А. Лубський висловлює думку, що метою активної участі молоді є сприяння спільному благу, покращення якості життя і вирішення соціально важливих проблем суспільства (Лубской, 2019).

Метою статті $\epsilon$ дослідження проблеми взаємодії органів влади та молодіжних об'єднань на прикладі залучення молодих громадян до розробки та впровадження нормативно-правових актів у деяких країнах $\mathrm{CC}$ та обгрунтувати пропозиції щодо реалізації Стратегії розвитку державної молодіжної політики України 2030 року.

Молодіжна політика у країнах $С \mathrm{C}$ впроваджується по-різному, що зумовлено особливостями економічного та соціального розвитку територій. Молодь країн-членів СС зіткається 3 проблемами, ступінь важкості 
яких індивідуальний у кожній державі, що істотно впливає на стан реалізації загальноєвропейської молодіжної політики та свідчить про недостатньо інтегрованість Свропи у здійсненні спільної молодіжної роботи.

У січні 2020 р. Комітетом міністрів Ради Європи була прийнята Стратегія молодіжного сектору 2030, яка заснована на таких пріоритетних цінностях Ради Свропи, як: демократія, права людини та верховенство права. Документом підкреслено важливість залучення молоді до прийняття управлінських рішень та збільшення участі молоді у соціально-політичних процесах, створення нових форм зайнятості молодих громадян, необхідності збільшення уваги молоді до екологічного питання, використання нових інформаційних та цифрових технологій (Resolution CM/Res (2020)2 on the Council of Europe youth sector strategy 2030). Перед підписанням Стратегії було прийнято резолюцію Ради СС та представників урядів держав-членів $Є С$ з питань європейської співпраці у молодіжній галузі: Молодіжна стратегія СС на 2019-2027 роки, в якій були визначені основні положення та затверджений план роботи щодо підготовки реалізації стратегіï (Rezolucja Rady Unii Europejskiej i przedstawicieli rządów państw członkowskich zebranych w Radzie w sprawie ram europejskiej współpracy na rzecz młodzieży: Strategia Unii Europejskiej na rzecz młodzieży na lata 20192027, 2019).

Важливу роль у підготовці Стратегії відіграла Об'єднана рада у справах молоді (Joint Council on Youth (CMJ), представники якої приймали участь на всіх етапах формування документу. Для Ради Свропи молодь є партнером, який відіграє основну роль в укріпленні демократичних процесів та в збереженні принципів діяльності міжнародної організації.

31 липня 2019 р. вступила в силу Резолюція Ради та представників країн-членів, які зустрічаються у Раді, та встановлюють керівні принципи управління молодіжним діалогом (Resolution of the Council and of the representatives of the Member States meeting within the Council establishing guidelines on the governance of the EU Youth Dialogue, 2019), в якій зазначено, що молодіжний діалог - $\epsilon$ центральним інструментом участі молоді СС та інших європейських країнах, ключові елементи якого включають прямий діалог між особами, що приймають рішення, і молодими людьми й їх представниками, постійне партнерство в управлінні процесом на місцевому, національному та європейському рівнях.

Так наприклад, свідченням діалогу між молоддю та органами влади у Німеччині, що триває, є створена структура - Федеральна рада молоді (Landesjugendringe), члени якої беруть участь в обговоренні та вирішенні актуальних питань молоді, а також представляють інтереси молодих громадян перед суспільством. У країні виокремлюють різні види участі населення, зокрема і молоді, а саме: не політична та політична участь, які включають цивільно-громадські, громадсько-ініціативні і волонтерські соціальні практики, з іншого боку, присутні інституціональні практики безпосередньої і представницької демократії (Ekman, \& Amne, 2012).

Завдяки спільній співпраці Ради молоді та уряду Німеччини у 2019 р., було прийнято Національну молодіжну стратегію або «Спільна молодіжна стратегія федерального уряду» (Jugendstrategie), яка охоплює 9 основних напрямів молодіжної роботи, а саме: майбутне, діалог поколінь та образи молоді; участь, прихильність та демократія; міські та сільські простори, житло та культура; різноманітність та залучення; освіта, робота і свобода; мобільність молоді та цифрові проблеми; навколишнє середовище; здоровий спосіб життя; Свропа та світ.

Таким чином, у Німеччині продуктом співпраці влади та молоді стала Національна молодіжна стратегія. Автори стратегії вважають, що вона повністю відповідає меті молодіжної політики ЄС та охоплює всіх представників молодого населення країни. Відповідальним 
органом публічної влади за іiі реалізацію визначено Федеральне Міністерство у справах сім’ї, людей похилого віку, жінок та молоді.

Молодіжна політика Франції, як і вся молодіжна політика Свропи, є крос-секторальною, основана на чисельних механізмах взаємодії різних міністерств. Крім того, до іiі реалізації залучені не тільки державні органи, а й громадські об'єднання. Указом прем'єр-міністра Франції від 12 жовтня 2016 р. № 2016-1377 «Про створення Ради 3 орієнтації молодіжної політики» (Conseil d'orientation des politiques de jeunesse (COJ)) створено Раду, яка є прикладом міжсекторальної співпраці та підтримує постійний діалог між всіма учасниками молодіжної роботи (Décret n 2016-1377, 2016).

Уряд країни останній час приділяє велику увагу участі молодих громадян у прийнятті рішень, так згідно указу президента Франції від 24 травня 2017 р. № 2017-1080 міністру народної освіти було доручено розробити та впровадити державну політику щодо молоді, направлену на міжвідомчу, наскрізну роботу для молодих громадян на всіх рівнях державної та регіональної політики. Як результат було прийнято наскрізний документ: «Політика сприяння молоді. Стратегії трансверсальної політики» (Politique en faveur de la jeunesse. Présentation stratégique de la politique transversale), який спирається на взаємодію між секторами, територіями, стейкхолдерами молодіжної роботи (Politique en faveur de la jeunesse,2020) та направлений на подальше поглиблення міжгалузевого та міжтериторіального (вертикального та горизонтального) підходів до розробки молодіжної політики що, вочевидь, посилюватиме диференціацію молодіжної політики та засоби іiі реалізації (Тарасенко, 2020). В акті зазначені стратегічні вектори дії уряду щодо молоді Франції, а саме: розвиток, сприяння мобільності; освіта; сприяння зайнятості та професійна інтеграція; боротьба з нерівністю на шляху до самостійності; покращення жит34 лових умов (Politique en faveur de la jeunesse, 2020). Активну участь у розробці і впровадженні Стратегії бере Рада 3 орієнтації молодіжної політики.

Аналізуючи країни східної Європи, які є членами $\mathrm{CC}$, звертаємо увагу на Польщу, де першим і єдиним послідовним документом 3 підтримки молоді була Національна стратегія для молоді 2003-2014 рр., яка включала 6 основних стратегічних цілей, а саме: створення і вимірювання можливостей для розвитку, самореалізації молодого покоління; створення можливостей для розвитку власної справи; запобігання маргіналізації молодого покоління; розвиток міжнародного співробітництва; створення молодіжної інформаційної системи; освіта та постійний розвиток молодіжних працівників.

Сьогодні шляхи розвитку, підтримки та гарантії молоді зазначені у Стратегії відповідального розвитку до 2020 р. (з перспективою до 2030 р.) (Strategia na rzecz Odpowiedzialnego Rozwoju do roku 2020 (z perspektywą do 2030 r.), 2017).

Після прийняття Сенатом Республіки Польща резолюції від 13 лютого 2018 р. «Інтегрована молодіжна політика», молодіжна політики розглядається в Польщі, як частина сімейної політики, мета якої у питаннях молоді підтримувати розвиток молодих громадян і протидіяти наявним загрозам.

Не дивлячись на те, що в країні існують громадські об'єднання Польська рада молодіжних організацій, Рада у справах дітей та молоді їх співпраця з владою обмежується консультаціями, активну роботу щодо підготовки рекомендацій для польської молодіжної політики веде Інститут комплексної профілактики (IPZIN), який адвокатує впровадження в країні єдиної комплексної молодіжної політики та підготував Декларацію «Молодь на порозі нового віка незалежності» (Młodzież u progu nowego stulecia Niepodległej). Декларацію підтримало 36 громадських об'єднань, проте процес адвокаційної кампанії триває і 
дотепер (Partycypacja obywatelska młodzieży w regionie Południowego Bałtyku Przykład Litwy, Polski I Szwecji, 2020). Нерезультативність та обмеженість діалогу свідчить про відсутність системної молодіжної роботи в країні та інерцію, можливий формалізм громадянських ініціатив і неурядових організацій, які обмежують можливості третього сектору опонувати владі.

У Чеській Республіці діє Національна молодіжна стратегія 2014 - 2020 pp. (Koncepce podpory mládeže na období 2014 - 2020), яка базується на 3 пріоритетах (стопах), а саме: полегшення процесу дорослішання (перехід до незалежної, свідомої та відповідальної особистості); визначення реальних потреб та можливостей молоді; просування потенціалу молоді з користю для суспільства (Koncepce podpory mládeže na období 2014 - 2020, 2014).

Ця стратегія стала результатом спільних консультацій між владою та представниками молоді, які відбувались під час круглих столів та Національної молодіжної конференції (2013 р.), що крім того, сприяло налагодженню структурованого діалогу між органами влади та молодими громадянами. Ефективна молодіжна політика має засновуватися на співпраці всіх зацікавлених сторін і при тісному контакті 3 молоддю, а структурований діалог спонукає молодь і посадовців Чехії спільно обговорювати і враховувати результати цих обговорень у політичному процесі. Структурований діалог 3 молоддю країни став постійним майданчиком для спільних дискусій та $є$ частиною структурованого діалогу СС з молоддю та молодіжними організаціями, що надає можливість молодим громадянам Чеської республіки отримати зворотній зв'язок і думку щодо формування політики участі молоді у політичному та громадському житті країни від експертів Євроспільноти.

Щодо Угорщини, то чинна Національна молодіжна стратегія (Nemzeti Ifjúsági Stratégia 2009 - 2024) має на меті створення соціального простору для підтримки, заохочення індивідуальної та громадської діяль- ності молоді, iї інтеграцію у доросле життя, ефективну роботу державних і громадських організацій, які допомагають цій цільовій групі та розвиток творчого, інтелектуального потенціалу молодих громадян, який був би корисний країні і Європі (Nemzeti Ifjúsági Stratégia, 2009).

Особлива увага у зазначеному документі приділяється створенню рівних можливостей, збереженню культурних традицій, підтримці угорської молоді яка проживає на території країни та за іiі межами, налагодження взаємозв'язків між угорською молоддю з молоддю з інших країн ЄС.

Відповідальним органом за реалізацію Стратегії визначено Департамент у справах молоді Міністерства людських ресурсів Угорщини (Ifjúságügyi Főosztály Emberi Erőforrások Minisztériuma). Не дивлячись на те, що у стратегії прописані основні кроки щодо підвищення участі молоді у політичному та громадському житті, а саме: зміцнення системи адвокації інтересів студентів; заохочення молоді до участі у молодіжних суспільних справах; розвиток та навчання навичкам і методам активної громадянської позиції; підвищення рівня участі молодіжних громадських об'єднань у процесі прийняття рішень, проте сьогодні в країні залучення молоді до прийняття рішень відбувається формально, так до 2017 р. функціонував урядовий консультативний орган «Національний молодіжний експертний форум», координацію якого здійснював заступник державного секретаря у справах молоді та спорту Міністерства людських ресурсів, а не представник громадськості, робота експертного форуму здійснювалась за 6 тематичними напрямками, до складу яких входили представники молодіжних громадських організацій (Ifjúsági Szakmai Egyeztető Fórum, 2013). Метою створення консультативного органу була підтримка скоординованої політики у сфері молоді та моніторинг реалізації Національної стратегії. Сьогодні функції Молодіжного експертного форуму виконує «Круглий стіл для молоді», 
до роботи якого залучені лідери громадського сектору, проте діалог влади та молоді є більш формальним.

На підставі вищезазначеного, можемо зробити висновок, що описані країни мають різний досвід залучення молоді до підготовки стратегічних документів, проте наявність національної стратегії розвитку молодіжної політики свідчить про обраний вектор молодіжної роботи, про наявний план дій на певні роки, а також про часткове залучення молодих громадян до підготовки впровадження документів. На жаль, це може свідчити про недостатній рівень комунікації між органами публічної влади, молоддю та їі громадськими об'єднаннями та необхідність пошуку нових підходів та інструментів побудови публічного діалогу у цій сфері з урахуванням особливостей досвіду кожної країни та на основі єдиних підходів до розвитку методів публічного управління.

Вважаємо, що адаптація досвіду таких країн, як Франція та Німеччина у підготовці та реалізації стратегії молодіжної політики позитивно вплине на розвиток молодіжної роботи в Україні. У період коли українська стратегія розвитку молодіжної політики до 2030 р. перебуває у стадії обговорення, вважаємо доцільним надати рекомендації щодо застосувати кращих практик впровадження та залучення молоді до підготовки документу до затвердження. Аналізу ефективності iї впровадження на території країни, так Є.Бородін висловлює думку, що нинішній стан стратегічного забезпечення у сфері державної молодіжної політики в Україні можна визначити як такий, що не відповідає вимогам як стратегічного планування, так й розвитку молодіжної політики (Бородін, 2019), тому на нашу думку, реалізації напрямів новоприйнятої Стратегії повинна бути скоординованою діяльністю органів публічної влади у партнерстві з інститутами громадянського суспільства .

Взагалі основне завдання стратегії сприяти посиленню впливу і нарощування масштабів зусиль, прикладених на національному, регіо36 нальному рівнях з метою задоволення потреб молоді, зміцнення потенціалу та розширення прав молоді в усьому іiі різноманітті, а також забезпечити іï участь у здійсненні та огляді документів, аналізу стану реалізації державної молодіжної політики і в прийнятті наступних заходів та кроків у іiі реалізації.

Вважаємо, що проєкт Закону України «Про основні засади молодіжної політики» має спиратись на стратегічні орієнтири розвитку молодіжної політики країни, з урахуванням європейського вектору держави, що ще раз підкреслює важливість наявності сучасної стратегії. Стратегія розвитку молодіжної політики до 2030 р. повинна стати цілісним документом, в якому зазначена система ідей, визначені найважливіші та сучасні цілі, завдання, пріоритети та заходи державної молодіжної політики, спрямованої на забезпечення стратегії держави у формуванні умов інтелектуального, технічного, соціального, культурного потенціалу молоді, з урахуванням взаємозв'язку між розвитком молодих громадян та цілями сталого розвитку.

У докладі Генерального Секретаря ООН від 27 червня 2017 р. рекомендовано країнам-членам розвивати та укріплювати наявні національні стратегії з питань молоді, підтримувати погоджені, міжсекторальні зусилля відповідно до Всесвітньої програми дій відносно молоді, і Повісткою дня у напрямі сталого розвитку до 2030 р. (Доклад Генерального секретаря $\mathrm{OOH}, 2017)$. Це дасть можливість взаємного підкріплення за допомогою двокомпонентного підходу, який передбачає урахування інтересів молоді в національному плані сталого розвитку та вивчення проблем сталого розвитку в молодіжній роботі.

Проєкт національної стратегії розвитку державної молодіжної політики до 2030 р. обговорювався на громадських слуханнях по областях, представники громадськості, експерти мали змогу надати свої пропозиції та зауваження. До обговорення була залучена і Національна молодіжна рада, яка надала письмові рекомендації. 
Висновок. Вважаємо доцільним запропонувати використання для оцінки Стратегії один із найсучасніших інструментів моніторингу молодіжної політики, такий як Індекс благополуччя молоді, що дасть змогу багатофакторного оцінювання стану благополуччя молоді на території, а це, у свою чергу, сприятиме узагальненню стану молоді в країні та ефективність впровадження Стратегії. Методику для розрахунку індексу розроблено Інститутом демографії та соціальних досліджень ім. М. В. Птухи НАНУ (ІДСД) та Представництвом Фонду ООН в галузі народонаселення (UNFPA), яка включає наступні блоки опитування молоді, а саме: соціально-демографічні дані, освіта, здоров'я та здоровий спосіб життя, економічні можливості, участь у політичному та громадському житті, інформаційно-комунікаційні технології, безпека та захищеність (Благополуччя молоді в містах, 2018).

Крім того, необхідно звернути увагу на вдосконалення навичок інтеркультурної компетенції серед молоді, забезпечення інформаційної безпеки та ефективне використання цифрових технологій, запобігання торгівлі людьми серед молоді, заохочення екологічних ініціатив, політик направлених на зміцнення молодіжного потенціалу, в якості рушійної сили змін, необхідної для вирішення екологічних проблем різного рівні: пришвидшення забруднення повітря, невідповідальне споживання, дегра- дація навколишнього середовища. Важливим елементом у реалізації стратегії має стати ефективне партнерство заради стійкого розвитку держави.

Відкритим залишається питання перепідготовки фахівців, підвищення кваліфікації, компетентності молодіжних працівників, які щоденно працюють 3 молоддю, особливо в органах публічної влади, а розробка освітньої програми для перепідготовки спеціалістів дасть змогу значно покращити надання послуг молодим громадянам.

Недостатньо уваги в Стратегії приділено питанню розвитку та підтримки молоді в новостворених об'єднаних територіальних громадах. Важливим є врахування заходів щодо заохочення молоді залишатись на територіях, через підтримку бізнес-проектів, створення можливостей для реалізації потенціалу молоді.

Подальше поглиблення знань за цією проблематикою передбачає розкриття: основних аспектів розвитку молодіжної політики в $\mathrm{CC}$, засобів забезпечення діалогу між основними стейкхолдерами молодіжної роботи Свропи та перспектив співпраці з українськими суб'єктами молодіжної політики; впливу співпраці на ефективність реалізації спільних проектів мобільності молоді між країнами СС та Україною та державну молодіжну політику України в цілому.

\section{БІБЛІОГРАФІЧНІ ПОСИЛАННЯ}

Баронина А. А., Зуляр Р. Ю. Реализация государственной молодежной политики на современном этапе в странах Европы. Известия Иркутского государственного университета. Серия Политология. Религиоведение. 2019. T. 30. С. 40-53. URL: https://doi.org/10.26516/2073-3380.2019.30.40 (дата звернення: 01.11.2020)

Благополуччя молоді в містах : практ. посібник / Макарова О., Саріогло В., Герасименко Г., Вороненко О. Київ, 2018107 с.

Бородін С. І. Стратегія розвитку державної молодіжної політики в Україні: досвід, стан та перспективи. Молодіжна політика та молодіжна робота : матеріали III Всеукр. наук.- практ. конф. за міжнарод. участю, 14 грудня 2018 р., м. Дніпро / за заг. ред. С. І. Бородіна. Дніпро : ДРІДУ НАДУ, 2019. 57 с., С. 3 - 8. URL: http:// www.dridu.dp.ua/konf/konf_dridu/2018_material_konference.pdf

Доклад Генерального секретаря ООН «Связь развития молодежи с устойчивым развитием». URL: https:// undocs.org/pdf?symbol=ru/A/72/190 (дата звернення: 01.11.2020).

Лубской А. В. Молодежная политика и гражданское участие молодежи Франции. Философско-правовые аспекты правовой политики государства. Философия права. 2019. № 3. С. 89-94. 
Молодежная работа (Рекомендация CM/Rec(2017)4 и пояснительный меморандум). URL : https://rm.coe.int/ recommendation-cmrec-2017-4-and-explanatory-memo-rus/16808e3d83 (дата звернення: 02.11.2020).

Тарасенко Т. М. Трансверсальність як виклик молодіжної політики на регіональному та місцевому рівні. Молодіжна політика та молодіжна робота : матеріали IV Всеукр. наук.- практ. конф. за міжнарод. участю, 20 грудня 2019 р., м. Дніпро / за заг. ред. С. I. Бородіна. Дніпро : ДРІДУ НАДУ, 2020. 110 с., C. 21 - 23. URL: http://www.dridu.dp.ua/konf/konf_dridu/material_conf_20-12-2019.pdf

Décret $n^{\circ} 2016-1377$ du 12 octobre 2016 portant création du Conseil d'orientation des politiques de jeunesse. URL: https://www.legifrance.gouv.fr/jorf/id/JORFTEXT000033242072?r=opgLwvZRbL (дата звернення: 02.11.2020)

Ekman J., Amne E. Political participation and civic engagement: towards a new typology : Human Affairs. De Gruyter. 2012. Vol. 22. Issue 3 C. 283-300.

Ifjúsági Szakmai Egyeztető Fórum. URL: https://emmiugyfelszolgalat.gov.hu/sport/ifjusagi-szakmai-egyeztetoforum/ifjusagi-szakmai-egyezteto-forum (дата звернення: 03.11.2020)

Koncepce podpory mládeže na období 2014-2020. URL: https://www.msmt.cz/file/33599 (дата звернення: 03.11.2020).

Nemzeti Ifjúsági Stratégia. URL: https://emmiugyfelszolgalat.gov.hu/ifjusagugy/nemzeti-ifjusagi/nemzetiifjusagi-strategia (дата звернення: 03.11.2020).

Partycypacja obywatelska młodzieży w regionie Południowego Bałtyku Przykład Litwy, Polski I Szwecji URL: https://zie.pg.edu.pl/documents/61628112/0/PARTYCYPACJA-OBYWATELSKA-M\%C5\%81ODZIE\%C5\%BBYW-REGIONIE-PO\%C5\%81UDNIOWEGO-BA\%C5\%81TYKU-PDF C.35 (дата звернення: 03.11.2020)

Politique en faveur de la jeunesse. URL: https:/www.performance-publique.budget.gouv.fr/sites/performance publique/files/farandole/ressources/2020/pap/pdf/DPT/DPT2020_jeunesse.pdf (дата звернення: 03.11.2020)

Resolution CM/Res (2020)2 on the Council of Europe youth sector strategy 2030. URL: https://rm.coe. int/0900001680998935 (дата звернення: 03.11.2020).

Resolution of the Council and of the representatives of the Member States meeting within the Council establishing guidelines on the governance of the EU Youth Dialogue. URL: https://eur-lex.europa.eu/legal-content/EN/ TXT/?qid=157312286051

5\&uri=CELEX:42019Y0605(01)\&from=EN (дата звернення: 02.11.2020).

Rezolucja Rady Unii Europejskiej i przedstawicieli rządów państw członkowskich zebranych w Radzie w sprawie ram europejskiej współpracy na rzecz młodzieży: Strategia Unii Europejskiej na rzecz młodzieży na lata 20192027. URL: https://eur-lex.europa.eu/legalcontent/PL/TXT/PDF/?uri=CELEX:42018Y1218(01)\&from=EN (дата звернення: 02.11.2020).

Strategia na rzecz Odpowiedzialnego Rozwoju do roku 2020 (z perspektywą do 2030 r.). URL: https://www.gov. pl/web/fundusze-regiony/informacje-o-strategii-na-rzecz-odpowiedzialnego-rozwoju. (дата звернення: 02.11.2020).

What is the EU Youth Dialogue? European Youth Portal. URL: https://europa.eu/youth/eu/article/266/66786_en. (дата звернення: 03.11.2020).

\section{REFERENCES}

Baronina, A. A., \& Zulyar, R. Yu. (2019), Realizatsiya gosudarstvennoy molodezhnoy politiki na sovremennom etape $\mathrm{v}$ stranah Evropyi [Implementation of state youth policy at the present stage in European countries]. Izvestiya Irkutskogo gosudarstvennogo universiteta. Seriya Politologiya. Religiovedenie - The Bulletin Of Irkutsk State University. Series «Political Science and Religion Studies», 30, 40-53. Retrieved from https://doi. org/10.26516/2073-3380.2019.30.40 [in Russian].

Borodin, Ye.I. (2019). Stratehiia rozvytku derzhavnoi molodizhnoi polityky v Ukraini: dosvid, stan ta perspektyvy [Strategy of development of the state youth policy in Ukraine: experience, condition and prospects]. Proceedings of All-Ukrainian Scientific and Practical Conference for international participation: Molodizhna polityka ta molodizhna robota - Youth policy and youth work. Ye. I. Borodin (Ed.). (pp. 3-8). Dnipro: DRIDU NADU. Retrieved from http://www.dridu.dp.ua/konf/konf_dridu/material_conf_20-12-2019.pdf [in Ukrainian].

Doklad Generalnogo sekretarya OON «Svyaz razvitiya molodezhi s ustoychivyim razvitiem» [Report of the UN Secretary General "Linking youth development to sustainable development"]. Retrieved from https://undocs. org/pdf?symbol=ru/A/72/190 [in Russian].

Lubskoy, A. V. (2019). Molodezhnaya politika i grazhdanskoe uchastie molodezhi Frantsii [Youth policy and civic participation of youth in France]. Filosofsko-pravovyie aspektyi pravovoy politiki gosudarstva. Filosofiya prava - Philosophical and legal aspects of state legal policy. Philosophy of law, 3, 89-94. [in Russian]. 
Molodezhnaya rabota (Rekomendatsiya CM/Rec (2017)4 i poyasnitelnyiy memorandum) [Youth work (CM / Rec (2017)4 and explanatory memorandum)]. Retrieved from https://rm.coe.int/recommendation-cmrec-2017-4-andexplanatory-memo-rus/16808e3d83 [in Russian].

Décret $\mathrm{n}^{\circ} 2016-1377$ du 12 octobre 2016 portant création du Conseil d'orientation des politiques de jeunesse. Retrieved from https://www.legifrance.gouv.fr/jorf/id/JORFTEXT000033242072?r=opgLwvZRbL.

Ekman, J., \& Amne, E. (2012). Political participation and civic engagement: towards a new typology: Human Affairs. De Gruyter, 22 (3), 283-300.

Ifjúsági Szakmai Egyeztetö Fórum. Retrieved from https://emmiugyfelszolgalat.gov.hu/sport/ifjusagiszakmai-egyezteto-forum/ifjusagi-szakmai-egyezteto-forum.

Koncepce podpory mládeže na obdobi 2014 - 2020. Retrieved from https://www.msmt.cz/file/33599.

Nemzeti Ifjúsági Stratégia. Retrieved from https://emmiugyfelszolgalat.gov.hu/ifjusagugy/nemzeti-ifjusagi/ nemzeti-ifjusagi-strategia.

Partycypacja obywatelska młodzieży $w$ regionie Poludniowego Battyku Przykład Litwy, Polski I Szwecji Retrieved from https://zie.pg.edu.pl/documents/61628112/0/PARTYCYPACJA-OBYWATELSKAM\%C5\%81ODZIE\%C5\%BBY-W-REGIONIE-PO\%C5\%81UDNIOWEGO-BA\%C5\%81TYKU-PDF C.35

Politique en faveur de la jeunesse. (2020). Retrieved from https://www.performance-publique.budget.gouv. fr/sites/performance_publique/files/farandole/ressources/2020/pap/pdf/DPT/DPT2020_jeunesse.pdf

Resolution CM/Res(2020)2 on the Council of Europe youth sector strategy 2030. Retrieved from https:// rm.coe.int/0900001680998935

Resolution of the Council and of the representatives of the Member States meeting within the Council establishing guidelines on the governance of the EU Youth Dialogue (2019) Retrieved from https://eur-lex. europa.eu/legal-content/EN/TXT/?qid=1573122860515\&uri=CELEX:42019Y0605(01)\&from=EN.

Rezolucja Rady Unii Europejskiej i przedstawicieli rządów państw członkowskich zebranych w Radzie w sprawie ram europejskiej współpracy na rzecz młodzieży: Strategia Unii Europejskiej na rzecz młodzieży na lata 2019-2027 (2019). Retrieved from https://eur-lex.europa.eu/legal-content/PL/TXT/PDF/?uri=CELEX:42018Y $1218(01) \&$ from $=\mathrm{EN}$.

Strategia na rzecz Odpowiedzialnego Rozwoju do roku 2020 (z perspektywą do 2030 r.) (2020). Retrieved from https://www.gov.pl/web/fundusze-regiony/informacje-o-strategii-na-rzecz-odpowiedzialnego-rozwoju.

Tarasenko, T. M. (2020). Transversalnist yak vyklyk molodizhnoi polityky na rehionalnomu ta mistsevomu rivni [Transversality as a challenge to youth policy at the regional and local levels]. Proceedings of All-Ukrainian Scientific and Practical Conference for international participation: Molodizhna polityka ta molodizhna robota Youth policy and youth work. Ye. I. Borodin (Ed.). (pp. 21-23). Dnipro: DRIDU NADU. Retrieved from: http:// www.dridu.dp.ua/konf/konf_dridu/material_conf_20-12-2019.pdf [in Ukrainian].

What is the EU Youth Dialogue? European Youth Portal. (2019) Retrieved from https://europa.eu/youth/eu/ article/266/66786_en.

\section{Несват Тетяна}

Аспірантка

Дніпропетровський регіональний інститут

державного управління Національної академії державного управління при Президентові України

Email: nesvat.home@gmail.com

\section{Nesvat Tetiana \\ Ph.D.Student}

Dnipropetrovsk Regional Institute of Public Administration National Academy of Public Administration under the President of Ukraine

Цитування: Несват, Т. (2020). Взаємодія органів публічної влади та молодіжних громадських об'єднань щодо підготовки стратегічних документів у сфері молодіжної політики в країнах ЄС. Аспекти публічного управління, 8 (5), 30-39. doi: 10.15421/152091

Citation: Nesvat, T. (2020). Vzaiemodiia orhaniv publichnoi vlady ta molodizhnykh hromadskykh obiednan shchodo pidhotovky stratehichnykh dokumentiv u sferi molodizhnoi polityky v krainakh YeS [Cooperation between public authorities and non-governmental youth associations in preparing the strategic documents in the field of youth policy in EU countries]. Public administration aspects, 8 (5), 30-39. doi: 10.15421/152091 